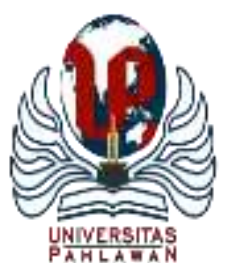

\title{
JURNALBASICEDU
}

Volume 6 Nomor 1 Tahun 2022 Halaman 1297 - 1310

Research \& Learningin Elementary Education

https://jbasic.org/index.php/basicedu

\section{Media Komik Elektronik Terintegrasi Augmented Reality dalam Pembelajaran Sistem Peredaran Darah Manusia di Sekolah Dasar}

\author{
Kartika Dwi Ningrum $^{1 凶}$, Erry Utomo ${ }^{2}$, Arita Marini $^{3}$, Bramianto Setiawan ${ }^{4}$ \\ Program Studi Pendidikan Dasar, Universitas Negeri Jakarta, Indonesia ${ }^{1,2,3,4}$ \\ E-mail: kartikadwiningrum9918817030@mhs.unj.ac.id ${ }^{1}$, erry30.utomo@gmail.com² ${ }^{2}$, $\underline{\text { aritamarini @ unj.ac.id }}^{3}$, \\ sbramianto@unipasby.ac.id ${ }^{4}$
}

\begin{abstract}
Abstrak
Penelitian ini bertujuan untuk menghasilkan komik elektronik sistem peredaran darah manusia yang terintegrasi augmented reality dalam meningkatkan minat belajar siswa sekolah dasar. Penelitian ini merupakan penelitian research and development yang menghasilkan media pembelajaran menarik minat belajar. Kemudian produk diuji coba dengan menggunakan metode eksperimen semu (quasi experiment) dalam bentuk nonequivalent pretest-posttest control group design. Validasi produk melibatkan ahli materi, bahasa, media serta validasi kelayakan produk. Uji keterbacaan peserta didik melalui uji coba perorangan, uji coba kelompok kecil dan uji coba lapangan. Teknik pengumpulan data yang digunakan adalah wawancara, observasi, dan angket. Subyek penelitian yaitu kelas V SDN Manggarai 09 Jakarta Selatan yang terbagi dalam dua sampel, yaitu kelas eksperimen dan kelas kontrol. Berdasarkan hasil penelitian dapat disimpulkan bahwa media komik elektronik sistem peredaran darah terintegrasi augmented reality dapat meningkatkan minat belajar siswa. Implikasi studi ini untuk praktik pembelajaran sistem peredaran darah manusia dengan pemanfaatan media komik elektronik yang terintegrasi augmented reality untuk meningkatkan minat belajar siswa kelas V sekolah dasar.
\end{abstract}

Kata Kunci: komik elektronik, augmented reality, minat belajar, e-comic, pembelajaran IPA, sekolah dasar.

\begin{abstract}
This study aims to produce an electronic comic of the human circulatory system that is integrated with augmented reality in increasing the learning interest of elementary school students. This research is a research and development research that produces learning media to attract interest in learning. Then the product was tested using a quasi-experimental method in the form of a nonequivalent pretest-posttest control group design. Product validation involves material, language, media experts as well as product feasibility validation. Readability test of students through individual trials, small group trials and field trials. Data collection techniques used are interviews, observations, and questionnaires. The research subject is class V SDN Manggarai 09 South Jakarta which is divided into two samples, namely the experimental class and the control class. Based on the results of the study, it can be concluded that the augmented reality integrated circulatory system electronic comic media can increase students' interest in learning. The implication of this study is for the practice of learning the human circulatory system by utilizing augmented reality integrated electronic comic media to increase the learning interest of fifth grade elementary school students.
\end{abstract}

Keywords: electronic comics, augmented reality, interest in learning, e-comic, science learning, elementary school.

Copyright (c) 2022 Kartika Dwi Ningrum, Erry Utomo, Arita Marini, Bramianto Setiawan

Corresponding author :

Email : kartikadwiningrum_9918817030@mhs.unj.ac.id

DOI : https://doi.org/10.31004/basicedu.v6i1.2289

ISSN 2580-3735 (Media Cetak)

ISSN 2580-1147 (Media Online) 
1298 Media Komik Elektronik Terintegrasi Augmented Reality dalam Pembelajaran Sistem Peredaran Darah Manusia di Sekolah Dasar - Kartika Dwi Ningrum, Erry Utomo, Arita Marini, Bramianto Setiawan

DOI: https://doi.org/10.31004/basicedu.v6i1.2289

\section{PENDAHULUAN}

Minat belajar adalah hal yang penting dalam proses pembelajaran, terlebih di muatan pelajaran IPA yang masih bersifat abstrak dan sulit untuk dipahami apabila dalam penyampaiannya tidak menggunakan media pembelajaran (Nicolas et al., 2015). Penggunaan media augmented reality masih kurang pemanfaatannya di sekolah dasar, sehingga perlu adanya inovasi yang dihadirkan dalam pembelajaran di sekolah dasar.

Perlu adanya penelitian yang membahas bagaimana pentingnya media pembelajaran augmented reality untuk diaplikasikan dalam pembelajaran di sekolah dasar, hal ini bertujuan agar tujuan pembelajaran IPA dapat tersampaikan dengan baik melalui inovasi-inovasi media pembelajaran di dunia pendidikan.

Inovasi media pembelajaran dalam dunia pendidikan sangatlah banyak. Inovasi dapat diartikan sebagai kreativitas guru yang mengubah gaya dan metode mengajar (Kalyani \& Rajasekaran, 2018). Penggunaan media inovatif dalam pembelajaran yang membutuhkan keterbaruan dan mengubah gaya serta metode yang digunakan dalam pembelajaran sehingga mampu menarik minat belajar peserta didik agar senang menerima materi yang disampaikan oleh guru.

Guru yang mengajar dengan cara menyenangkan akan mengarahkan peserta didik untuk siap mengimplementasikan aktivitas-aktivitas belajar yang telah diberikan oleh guru di dalam kelas (Al-shara, 2015). Dalam hal ini guru sebagai pendidik sangat perlu untuk terus mencari cara apa saja metode pengajaran yang terbaru untuk meningkatkan kenyamanan peserta didik dalam belajar. Peserta didik yang nyaman dengan pengalaman belajar yang didapatkan dari gurunya akan membuat peserta didik berkomitmen dalam setiap kegiatan pembelajaran yang dilakukan di dalam kelas.

Metode inovatif yang guru temukan untuk digunakan dalam kegiatan pembelajaran di dalam kelas membuat peserta didik nyaman dan senang saat belajar. Kebahagiaan dan kegembiraan dalam kegiatan pembelajaran sangat dibutuhkan oleh peserta didik (Talebzadeh \& Samkan, 2011). Kebahagiaan dan keceriaan adalah dua hal yang sangat penting bagi murid dalam proses pembelajaran.

Berdasarkan kajian literatur tersebut, inovasi perlu dilakukan untuk dapat membuat minat belajar dan memancing perhatian peserta didik dalam proses pembelajaran, namun hal tersebut belum diimplementasikan sepenuhnya karna beberapa hal, yaitu:

Pertama, materi yang sulit. Salah satu materi yang sulit untuk disampaikan kepada peserta didik adalah materi tentang sistem peredaran darah manusia pada muatan pelajaran ilmu pengetahuan alam. Sistem peredaran darah manusia adalah materi yang berisikan tentang bagaimana peredaran darah terjadi di dalam tubuh manusia. Materi yang memiliki tingkat kesulitan tinggi harus disampaikan menggunakan banyak cara yang inovatif agar dapat diterima dengan baik oleh peserta didik. Sistem peredaran darah manusia sangat penting untuk dipelajari, tetapi dalam penerapannya membutuhkan level pemahaman yang tinggi. (Nicolas et al., 2015). Sistem peredaran darah manusia salah satu materi pelajaran yang sangat penting untuk dipelajari. Tetapi dalam prosesnya membutuhkan tingkat pemahaman yang tinggi karena sangat sulit jika hanya dipelajari menggunakan bahasa verbal. Sistem peredaran darah manusia adalah materi yang membutuhkan penyampaian yang baik, sehingga dibutuhkan media inovatif untuk memahami konsep materi tersebut (Nurharyani et al., 2015). Media pembelajaran yang inovatif sangat diperlukan dalam penyampaian materi pembelajaran sistem peredaran darah manusia. Sistem peredaran darah manusia adalah materi yang berisi tentang bagaimana sirkulasi darah berada di dalam tubuh manusia yang dimulai dari jantung hingga ke seluruh tubuh dan kembali lagi ke jantung. Materi sistem peredaran darah manusia yang abstrak akan membuat peserta didik kesulitan untuk memahami isi materi tersebut sehingga dibutuhkan bantuan media lain untuk membantu penyampaian materi menjadi lebih mudah dipahami dan menyenangkan bagi peserta didik. 
1299 Media Komik Elektronik Terintegrasi Augmented Reality dalam Pembelajaran Sistem Peredaran Darah Manusia di Sekolah Dasar - Kartika Dwi Ningrum, Erry Utomo, Arita Marini, Bramianto Setiawan

DOI: https://doi.org/10.31004/basicedu.v6i1.2289

Kedua, minat belajar. Minat belajar peserta didik dalam mengikuti pembelajaran IPA pun masih belum maksimal. Peserta didik cenderung lebih banyak mengobrol dan bosan saat pembelajaran. Oleh karena itu, perlu adanya sebuah gebrakan dan inovasi yang dapat memacu semangat peserta didik untuk mengikuti kegiatan pembelajaran IPA. Kurangnya minat belajar peserta didik berbanding lurus saat peserta didik mengalami kesulitan dalam memahami materi yang dapat pula disebabkan oleh guru yang kurang melakukan inovasi dalam penyampaian pembelajarannya. Prestasi peserta didik yang rendah disebabkan oleh keterbaruan guru yang juga rendah dalam mengemas proses pembelajaran (Jampel et al., 2018). Prestasi peserta didik yang rendah dapat disebabkan oleh guru yang kurang inovatif saat pembelajaran sehingga menyebabkan prestasi nilai IPA yang tergolong rendah. Kesalahan dalam proses pembelajaran semata-mata bukan hanya terdapat pada peserta didik, namun guru juga harus mengikuti proses perkembangan zaman dan mencari cara baru untuk menyegarkan kegiatan pembelajaran di dalam kelas sehingga proses kegiatan belajar mengajar menjadi lebih menyenangkan.

Ketiga, kurangnya media inovatif. Sebagian besar guru yang memegang kelas $\mathrm{V}$ adalah guru-guru senior yang memiliki keterbatasan dalam mencari dan menggunakan media inovatif. Media yang paling sering digunakan adalah media video. Sedangkan media pembelajaran berupa video memiliki kekurangan salah satunya yaitu, opposition atau pengambilan yang kurang tepat dapat menyebabkan timbulnya keraguan penonton dalam menafsirkan gambar yang dilihat (Daryanto, 2010b). Selain itu, kendala terbesarnya adalah ketidaktahuan bahan referensi terbaru untuk menemukan dan membuat media pembelajaran yang mampu menjadi penghubung untuk menyampaikan materi sistem peredaran darah.

Sistem peredaran darah manusia adalah materi kompleks sehingga perlu menggunakan alat bantu berupa media pembelajaran yang lebih inovatif (Nurharyani et al., 2015). Materi sistem peredaran darah manusia dapat menarik perhatian peserta didik dengan cara menggunakan ilustrasi gambar-gambar dalam penyampaiannya (Panjaitan \& Savitri, 2016). Komik merupakan media yang memiliki ilustrasi berwarna, alur cerita dengan perwatakan orang yang realistis sehingga menarik semua anak dari berbagai tingkat usia (Agatha et al., 2018).

Terlebih di masa pandemi, guru akan semakin sulit untuk menyampaikan materi sistem peredaran darah. Pandemi telah membuat sistem pembelajaran harus diubah secara drastis dari tatap muka menjadi pembelajaran jarak jauh (Nadeak, 2020). Sarana yang dapat digunakan dalam pembelajaran jarak jauh adalah dengan menggunakan media komik dalam bentuk elektronik. Media elektronik dapat membantu guru dan peserta didik memiliki ide-ide kreatif dan praktis (Meidasari, 2016).

Komik elektronik mampu menjadi solusi alternatif bagi masalah yang terjadi dalam proses pembelajaran (Derbel, 2019). Pembelajaran IPA sangat membutuhkan konsentrasi dan kemampuan membaca serta memahami soal yang tinggi sehingga dengan hadirnya komik dalam proses pembelajaran akan mampu mengatasi permasalahan tersebut. Menarik minat peserta didik untuk menyukai pelajaran masih dirasa sulit oleh sebagian besar guru. Oleh karena itu, buku komik mempunyai potensi luar biasa untuk mengembangkan ketertarikan dan keinginan membaca peserta didik, terutama pada materi IPA (Lin et al., 2015). Dalam proses pembelajaran IPA memiliki tujuan untuk dimaksudkan agar dapat memberikan bekal kepada peserta didik dengan tekanan penataan nalar dalam penerapan IPA.

Permasalahan utama dalam penelitian ini adalah minat belajar yang belum terbentuk dalam proses pembelajaran IPA di kelas 5 SDN Manggarai 09 sehingga penelitian research and development untuk pengembangan media pembelajaran komik elektronik ini akan dapat memfasilitasi pembelajaran sistem peredaran darah sehingga menjadi lebih konkret dalam penyampaiannya.

Meningkatkan minat belajar IPA peserta didik dapat dilakukan melalui berbagai penggunaan inovasi media pembelajaran di dalam kelas. Minat belajar adalah salah satu komponen penting dalam proses pembelajaran sehingga tujuan pembelajaran dapat tercapai dengan maksimal. Pembelajaran IPA memiliki 
1300 Media Komik Elektronik Terintegrasi Augmented Reality dalam Pembelajaran Sistem Peredaran Darah Manusia di Sekolah Dasar - Kartika Dwi Ningrum, Erry Utomo, Arita Marini, Bramianto Setiawan

DOI: https://doi.org/10.31004/basicedu.v6i1.2289

banyak materi akan dapat mudah dipahami jika memiliki minat belajar, karena minat belajar merupakan kecenderungan untuk memperhatikan dan mengenang berbagai kegiatan (Slameto, 2010). Minat belajar juga kecenderungan hati untuk ingin tahu terhadap sesuatu (Djaali, 2011). Minat belajar tidak terlepas dari bagaimana upaya guru dalam mengemas materi pelajaran sehingga keingintahuan dan minat belajar peserta didik dapat tumbuh. Salah satu cara yang dapat digunakan untuk meningkatkan minat belajar adalah dengan penggunaan augmented reality.

Penelitian mengenai augmented reality dilakukan oleh Fakhrudin membahas mengenai keberhasilan penggunaan AR dalam proses pembelajaran IPA untuk meningkatkan motivasi dan pemecahan masalah di kelas VIII (Fakhrudin, 2019). Berdasarkan penelitian tersebut, analisis data yang dilakukan menggunakan ANCOVA menunjukkan bahwa terdapat perbedaan signifikansi antara kelas yang kegiatan pembelajaran IPA menggunakan media AR dan yang tidak, sehingga menunjukan keberhasilan bahwa media AR dalam proses pembelajaran IPA dapat meningkatkan motivasi dan kemampuan memecahkan masalah di kelas VIII. Selain itu, penelitian yang dilakukan oleh Yuliana Wahyu menunjukkan bahwa penggunaan MAR (Mobile Augmented Reality) efektif digunakan dalam proses pembelajaran untuk meningkatkan literasi sains peserta didik kelas 4 sekolah dasar (Wahyu et al., 2020). Penelitian lain yang dilakukan oleh Zakia Nurhasanah menunjukkan bahwa AR dapat memberikan dampak positif untuk peserta didik dalam memahami konsep sains (Nurhasanah et al., 2019). Berdasarkan hasil analisis data menggunakan non-equivalent control group design menunjukkan terdapat perbedaan antara kelas yang menggunakan media AR dengan kelas yang tidak menggunakan media AR dalam proses pembelajaran IPA. Selain penggunaan AR, komik juga merupakan sebuah seni yang popular di kalangan anak-anak (Heru Dwi Waluyanto, 2005). Komik dapat digunakan sebagai sarana mengajarkan ilmu pengetahuan (Siregar \& Melani, 2019). Komik juga dapat digunakan sebagai sarana informasi ilmiah (Arroio, 2011). Komik juga memiliki cerita yang sederhana sehingga mudah diterima oleh anak-anak (Daryanto, 2010a).

Berdasarkan penelitian sebelumnya, belum ada penelitian yang membahas mengenai komik yang terintegrasi augmented reality dalam membelajarkan IPA kepada peserta didik di tingkat sekolah dasar. Hal ini merupakan gap penelitian yang akan dibahas sehingga dapat memberikan warna baru bagi penelitianpenelitian yang sudah dilakukan sebelumnya.

\section{METODE PENELITIAN}

Penelitian ini dilakukan dengan menerapkan metode penelitian pengembangan atau biasa dikenal dengan metode R \& D (Research and Development). Metode ini memfokuskan pada pengembangan media pembelajaran komik elektronik terintegrasi augmented reality yang akan dibuat sesuai dengan kebutuhan siswa kelas V sekolah dasar. Pengujian efektivitas penelitian ini menggunakan metode Quasi Experiment dengan pendekatan mixed method. Penelitian ini menggabungkan dua bentuk penelitian yang telah ada sebelumnya yaitu penelitian kualitatif dan penelitian kuantitatif.

Peneliti melakukan penelitian dan pengembangan media komik elektronik terintegrasi augmented reality pada materi sistem peredaran darah manusia untuk meningkatkan minat belajar IPA siswa sekolah dasar. Kelayakan media pembelajaran dikembangkan diperoleh melalui validasi oleh ahli materi, ahli media dan ahli bahasa. Selain itu juga dilakukan uji kelayakan oleh guru dan uji keterbacaan oleh peserta didik.

Peneliti juga akan menguji efektivitas media komik elektronik sistem peredaran darah manusia terintegrasi augmented reality terhadap minat belajar IPA siswa kelas V SDN Manggarai 09. Pengujian efektivitas penelitian ini menggunakan metode Quasi Experiment dengan pendekatan mixed method. Penelitian ini menggabungkan dua bentuk penelitian yang telah ada sebelumnya yaitu penelitian kualitatif dan penelitian kuantitatif. Menurut Creswell, penelitian campuran merupakan pendekatan penelitian yang 
mengombinasikan pendekaran kualitatif dan kuantitatif secara bersama-sama sehingga diperoleh data yang lebih komprehensif, valid, reliable dan obyektif (Creswell, 2011).

Penelitian dengan desain ini memungkinkan pengambilan sampel yang telah diorganisasikan ke dalam kelompok tertentu atau intact group. Rancangan yang akan digunakan dalam penelitian ini adalah PretestPosttest Control Group Design, dengan menggunakan dua kelas sebagai subyek penelitian yaitu, kelas eksperimen dan kelas kontrol menggunakan media ajar yang sama. Tahap awal yang dilakukan untuk kedua kelas, yaitu kelas eksperiman dan kelas kontrol dilakukan pengujian menggunakan soal pretest dan dengan mengerjakan instrumen yang sama dalam bentuk pernyataan untuk mengetahui minat belajar dari masingmasing-masing kelas. Tahap selanjutnya diberikan perlakuan yang berbeda dari kedua kelas yang diteliti. Pada kelas eksperimen diberi perlakuan dengan media pembelajaran menggunakan media komik elektronik terintegrasi augmented reality, sedangkan kelas kontrol menggunakan media ajar yang selama ini digunakan.

Setelah diberi perlakuan yang berbeda, kemudian ke dua kelas diberi angket untuk mengetahui minat belajar siswa. Untuk memudahkan memahami rancangan penelitian digambarkan seperti pada Tabel berikut:

Tabel 1. Rancangan Nonequivalent Pretest-Posttest Control Group Design

\begin{tabular}{lccc}
\hline \multicolumn{1}{c}{ Kelas } & Pre-test & Treatment & Post-test \\
\hline Eksperimen & $\mathrm{O}_{1}$ & $\mathrm{X}$ & $\mathrm{O}_{2}$ \\
\hline Kontrol & $\mathrm{O}_{3}$ & - & $\mathrm{O}_{4}$ \\
\hline
\end{tabular}

\section{Keterangan:}

$\mathrm{O}_{1} \quad$ : pretest pada kelas eksperimen

$\mathrm{O}_{2} \quad$ : posttest pada kelas eksperimen

$\mathrm{O}_{3} \quad$ : pretest pada kelas kontrol

$\mathrm{O}_{4} \quad$ : posttest pada kelas kontrol

$\mathrm{X} \quad$ : perlakuan pembelajaran dengan media komik elektronik terintegrasi augmented reality

Kegiatan penelitian dan pengembangan media pembelajaran komik elektronik sistem peredaran darah manusia terintegrasi augmented reality ini dilaksanakan di kelas V SDN Manggarai 09. Waktu penelitian akan dilaksanakan pada bulan September 2021 sampai dengan Desember 2021.

Subyek penelitian terdiri atas 3 siswa dalam uji coba perorangan, 10 siswa dalam uji coba kelompok kecil dan 22 siswa dalam uji coba lapangan.

Ada berbagai macam model penelitian pengembangan, untuk penelitian yang akan dilakukan dengan menerapkan model penelitian pengembangan Dick and Carey, meliputi 10 langkah, yaitu: 1) Mengidentifikasi tujuan pembelajaran (Identifying Instructional Goal); 2) Melakukan analisis pembelajaran (Conducting Instructional Analysis); 3) Mengidentifikasi tingkah laku dan karakteristik peserta didik (Identifying Entry Behaviors, Characteristics); 4) Merumuskan tujuan pembelajaran (Writing Performance Objectives); 5) Mengembangkan instrument penilaian (Developing Criterion-Referenced Test); 6) Mengembangkan strategi pembelajaran (Developing Instructional Strategy); 7) Mengembangkan dan memilih media (Developing and Selecting Instruction); 8) Merancang dan melaksanakan evaluasi formatif (Designing and Conducting Formative Evaluation); 9) Merancang dan mengembangkan evaluasi sumatif; 10) Merevisi terhadap media (Revising Instruction). (Dick et al., 2005)

Namun pada penelitian ini hanya sampai pada tahap sembilan, yaitu merevisi media pembelajaran. Pada tahapan ke sepuluh melakukan penilaian sumatif tidak dilakukan karena tidak masuk ke dalam desain pembelajaran.

Untuk melakukan validasi dari produk yang dikembangkan mengacu pada jenis data berupa data kuantitatif dan kualitatif. Data kuantitatif berupa informasi yang diperoleh dengan menggunakan angket setelah penggunaan media komik elektronik terintegrasi augmented reality. Data kualitatif berupa informasi 
1302 Media Komik Elektronik Terintegrasi Augmented Reality dalam Pembelajaran Sistem Peredaran Darah Manusia di Sekolah Dasar - Kartika Dwi Ningrum, Erry Utomo, Arita Marini, Bramianto Setiawan

DOI: https://doi.org/10.31004/basicedu.v6i1.2289

dari wawancara dengan guru kelas, komentar, tanggapan dan saran perbaikan berdasarkan hasil penilaian dari ahli materi, ahli media dan ahli bahasa. Selain itu juga melalui uji kelayakan berdasarkan hasil penilaian oleh guru yang mengajar di kelas 5 .

Penelitian ini menggunakan angket untuk mengetahui bagaimana respon minat belajar peserta didik sebelum dan sesudah menggunakan media komik elektronik sistem peredaran darah manusia terintegrasi augmented reality.

Wawancara bertujuan untuk mendapatkan informasi tentang karakteristik peserta didik di kelas 5 , standar kompetensi pada mata pelajaran IPA serta kesulitan-kesulitan yang ditemui oleh guru kelas 5 dalam proses pembelajaran di dalam kelas. Selain itu wawancara ini juga bertujuan untuk mengidentifikasi kebutuhan peserta didik dalam kegiatan pembelajaran.

Instrumen penelitian melalui tahap pengujian, yakni uji homogenitas, uji normalis, uji realibilitas dan uji beda.

Media pembelajaran yang dihasilkan dinyatakan layak harus dilakukan evaluasi secara menyeluruh. Untuk estimasi validitas dan reliabilitasnya melalui tahap uji coba produk yang pengukurannya menggunakan Skala Likert. Evaluasi dari Media pembelajaran ini merupakan skor rata-rata yang diperoleh dari jawaban kuesioner yang memiliki pilihan skor 1-5. Instrumen penelitian dalam bentuk angket dianalisis menggunakan Skala Likert dengan kriteria sebagai berikut:

Tabel 2. Skala Penilaian Instrumen

\begin{tabular}{cc}
\hline PILIHAN & SKOR \\
JAWABAN & \\
\hline SANGAT BAIK & 5 \\
\hline BAIK & 4 \\
\hline CUKUP & 3 \\
\hline KURANG & 2 \\
\hline SANGAT KURANG & 1 \\
\hline
\end{tabular}

Setelah itu dilakukan interpretasi dari skor yang diperoleh sebagai berikut:

Tabel 3. Interpretasi Skor

\begin{tabular}{cc}
\hline PRESENTASE & KRITERIA \\
\hline $\mathbf{8 1 \%}-\mathbf{1 0 0 \%}$ & Sangat layak \\
\hline $\mathbf{6 1 \%}-\mathbf{8 0 \%}$ & Layak \\
\hline $\mathbf{4 1 \%}-\mathbf{6 0} \%$ & Cukup layak \\
\hline $\mathbf{2 1 \%}-\mathbf{4 0 \%}$ & Kurang layak \\
\hline $\mathbf{0 \%}-\mathbf{2 0 \%}$ & Tidak layak \\
\hline
\end{tabular}

Hasil analisis data pada instrumen yang diberikan akan disajikan dalam bentuk tabel dan grafik. Teknik analisis data menggunakan uji-t.

$t=\frac{m d}{\sqrt{\frac{\sum x d^{2}}{n(n-1)}}}$

Dimana $t$ adalah skor uji-t, $M_{d}$ adalah rerata gain, $X_{d}$ deviasi skor gain terhadap rerata, $d$ adalah selisih skor sesudah dan skor sebelum dari tiap subyek, $\mathrm{X}_{\mathrm{d}}{ }^{2}$ adalah kuadrat deviasi skor gain terhadap reratanya, dan $\mathrm{n}$ adalah banyaknya sample (subjek penelitian). Untuk menentukan persentase keberhasilan digunakan perhitungan sebagai berikut: (Lestari \& Yudhanegara, 2017).

$p=\frac{s}{n} \times 100 \%$ 
1303 Media Komik Elektronik Terintegrasi Augmented Reality dalam Pembelajaran Sistem Peredaran Darah Manusia di Sekolah Dasar - Kartika Dwi Ningrum, Erry Utomo, Arita Marini, Bramianto Setiawan

DOI: https://doi.org/10.31004/basicedu.v6i1.2289

di mana $\mathrm{P}$ adalah persentase keberhasilan (\%), $\mathrm{S}$ adalah jumlah perolehan nilai, dan $\mathrm{N}$ adalah jumlah nilai maksimum. Komik elektronik sistem peredaran darah manusia terintegrasi augmented reality yang dikembangkan dikatakan layak, jika minimal tingkat kualitas yang dicapai kategori cukup baik.

\section{HASIL DAN PEMBAHASAN}

Penelitian yang dilakukan bertujuan untuk menghasilkan komik elektronik sistem peredaran darah manusia terintegrasi augmented reality. Media ajar yang dikembangkan diharapkan menjadi salah satu sumber belajar yang efektif sehingga minat belajar IPA siswa kelas V dapat meningkat.

Penelitian ini merupakan penyederhanaan dan penyesuaian dari model Dick and Carey sesuai kebutuhan penelitian 4 langkah, yaitu:

1. Tahap analisis kebutuhan, menghimpun data sebagai dasar untuk pengembangan produk. Tahapannya terdiri dari studi literatur dan studi lapangan.

2. Tahap desain produk, menganalisis kompetensi inti dan kompetensi dasar sesuai dengan materi yang akan dijadikan komik elektronik, yaitu materi sistem peredaran darah manusia. Kemudian dilanjutkan dengan mengumpulkan dan menganalisis materi yang disajikan dalam media pembelajaran komik.
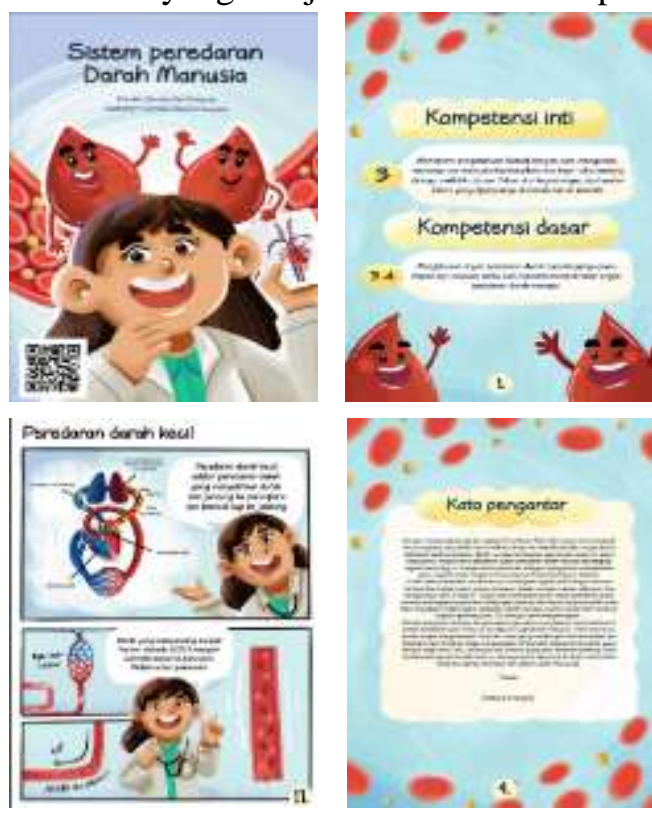

Gambar Desain Produk

3. Tahap evaluasi dan validasi, dilakukan pengujian terhadap media komik elektronik sistem peredaran darah manusia terintegrasi augmented reality. Pengujian dilakukan oleh ahli sebelum diujicobakan pada tahap implementasi. Validasi ahli terkait dengan kelayakan isi/materi, bahasa dan media. Hasil validasi oleh ahli ditunjukkan pada tabel 4.

Tabel 4. Hasil Validasi Para Ahli

\begin{tabular}{cccc}
\hline No. & Aspek & Presentasi (\%) & Kriteria \\
\hline 1 & Isi Materi & 92,1 & Sangat Layak \\
\hline 2 & Bahasa & 73 & Layak \\
\hline 3 & Media & 90,6 & Sangat Layak \\
\hline & Rata-rata & 85,23 & Sangat Layak \\
\hline
\end{tabular}


1304 Media Komik Elektronik Terintegrasi Augmented Reality dalam Pembelajaran Sistem Peredaran Darah Manusia di Sekolah Dasar - Kartika Dwi Ningrum, Erry Utomo, Arita Marini, Bramianto Setiawan

DOI: https://doi.org/10.31004/basicedu.v6i1.2289

Berdasarkan hasil uji validasi ahli diperoleh skor untuk aspek materi $92,1 \%$, aspek bahasa $73 \%$, dan aspek media 90,6\%. Rata- rata dari keseluruhan aspek adalah 85,23\% dengan kategori sangat layak. Dari data tersebut dapat disimpulkan bahwa media komik elektronik yang dikembangkan sangat layak digunakan sebagai sumber belajar siswa.

Uji kelayakan oleh guru kelas 5 bertujuan untuk mengetahui apakah komik elektronik yang dikembangkan sesuai dengan kebutuhan di lapangan sehingga dapat digunakan sebagai penunjang dalam kegiatan pembelajaran di kelas. Tabel 5 menunjukkan hasil uji kelayakan oleh guru

Tabel 5. Hasil Validasi Guru Kelas V

\begin{tabular}{|c|c|c|c|c|c|c|}
\hline \multirow{2}{*}{ No. } & \multirow{2}{*}{ Aspek } & \multicolumn{2}{|c|}{ Nilai } & \multirow{2}{*}{ Rata-rata } & \multirow{2}{*}{$\begin{array}{c}\text { Presentasi } \\
(\%)\end{array}$} & \multirow{2}{*}{ Kriteria } \\
\hline & & Guru 1 & Guru 2 & & & \\
\hline 1 & Isi Materi & 50 & 40 & 45 & 90 & Sangat Layak \\
\hline 2 & Bahasa & 15 & 14 & 14,5 & 96,7 & Sangat Layak \\
\hline 3 & Media & 35 & 34 & 34,5 & 96,6 & Sangat Layak \\
\hline \multicolumn{5}{|c|}{ Rata-rata } & 95,1 & Sangat Layak \\
\hline
\end{tabular}

Berdasarkan hasil validasi guru yang ditunjukkan pada tabel 5, diperoleh skor rata-rata dari keseluruhan aspek adalah 95,1\%. Skor ini menunjukkan bahwa media komik elektronik yang dikembangkan termasuk dalam kategori sangat layak digunakan sebagai media pembelajaran.

Setelah dilakukan uji kelayakan oleh validator ahli dan guru kelas 5, selanjutnya media komik elektronik disempurnakan berdasarkan saran dari para ahli dan guru kemudian diujicobakan kepada peserta didik. Uji coba media komik elektronik dilakukan sebanyak tiga kali, yaitu uji coba perorangan, uji coba kelompok kecil dan uji coba lapangan. Berikut data hasil uji coba dari peserta didik.

a. Uji Coba Perorangan

Uji coba perorangan dilakukan kepada 3 peserta didik, denganmenyeleksi berdasarkan kemampuan di bawah, setara, dan di atas rata- rata.

Tabel 6. Hasil Uji Coba Perorangan

\begin{tabular}{cccc}
\hline No. & Aspek & Presentasi (\%) & Kriteria \\
\hline 1 & Materi & 80 & Layak \\
\hline 2 & Kebahasa & 77,78 & Layak \\
\hline 3 & Penyajian & 80 & Layak \\
\hline & Rata-rata & 79,26 & Layak
\end{tabular}

Berdasarkan hasil uji coba perorangan yang ditunjukkan pada tabel 6, diperoleh skor rata-rata dari keseluruhan aspek adalah 79,26\%. Skor ini menunjukkan bahwa media komik elektronik sistem peredaran darah terintegrasi augmented reality yang dikembangkan termasuk dalam kategori layak digunakan sebagai media pembelajaran.

b. Uji Coba Kelompok Kecil

Uji coba kelompok kecil dilakukan kepada 10 peserta didik, dengan karakteristik yang berbeda dari uji coba perorangan. 
1305 Media Komik Elektronik Terintegrasi Augmented Reality dalam Pembelajaran Sistem Peredaran Darah Manusia di Sekolah Dasar - Kartika Dwi Ningrum, Erry Utomo, Arita Marini, Bramianto Setiawan

DOI: https://doi.org/10.31004/basicedu.v6i1.2289

Tabel 7. Hasil Uji Coba Kelompok Kecil

\begin{tabular}{cccc}
\hline No. & Aspek & Presentasi $\mathbf{( \% )}$ & Kriteria \\
\hline 1 & Materi & 90,55 & Sangat Layak \\
\hline 2 & Kebahasa & 90,00 & Sangat Layak \\
\hline 3 & Penyajian & 92,00 & Sangat Layak \\
\hline & Rata-rata & 90,85 & Sangat Layak \\
\hline
\end{tabular}

Berdasarkan hasil uji coba kelompok kecil yang ditunjukkan pada tabel 7, diperoleh skor rata-rata dari keseluruhan aspek adalah 90,85\%. Penjabaran dari setiap aspek yang dinilai, yaitu aspek materi memperoleh skor 90,55\%; aspek kebahasaan memperoleh skor 90\%; dan aspek penyajian memperoleh skor $92 \%$. Skor ini menunjukkan bahwa media komik elektronik yang dikembangkan termasuk dalam kategori sangat layak untuk dijadikan media pembelajaran.

c. Uji Coba Lapangan

Tabel 8. Hasil Uji Coba Lapangan

\begin{tabular}{cccc}
\hline No. & Aspek & Presentasi (\%) & Kriteria \\
\hline 1 & Materi & 93,02 & Sangat Layak \\
\hline 2 & Kebahasa & 92,00 & Sangat Layak \\
\hline 3 & Penyajian & 94,00 & Sangat Layak \\
\hline & Rata-rata & 93,01 & Sangat Layak \\
\hline
\end{tabular}

Berdasarkan hasil uji coba lapangan yang ditunjukkan pada tabel 8, diperoleh skor rata-rata dari keseluruhan aspek adalah 93,01\%. Penjabaran dari setiap aspek yang dinilai, yaitu aspek materi memperoleh skor 93,02\%; aspek kebahasaan memperoleh skor $92 \%$ dan aspek penyajian memperoleh skor $94 \%$. Skor ini menunjukkan bahwa media komik elektronik sistem peredaran darah manusia terintegrasi augmented reality ini termasuk kategori sang layak digunakan sebagai media pembelajaran.

4. Tahap produk akhir, berupa komik elektronik final yang telah diujicobakan dijadikan model produk yang siap diimplementasikan di lapangan.

\section{Hasil Uji Validasi Instrumen}

1. Uji Validitas Instrumen

Uji validitas dalam penelitian ini dilakukan untuk mengetahui apakah instrumen non tes yang digunakan layak dijadikan sebagai alat ukur untuk meningkatkan minat siswa. Uji ini melibatkan 10 responden yang dipilih secara acak pada kelas berbeda yang tidak termasuk dalam subyek penelitian. Berdasarkan hasil perhitungan diperoleh hasil butir soal yang dinyatakan valid tersaji dalam tabel di bawah ini.

Tabel 9. Hasil Uji Validitas Instrumen

\begin{tabular}{cccc}
\hline Instrumen & Jumlah Pernyataan & Valid & Tidak Valid \\
\hline Non tes & 20 & 20 & -
\end{tabular}

Berdasarkan Tabel 9, diketahui jumlah pertanyaan yang dilakukan pengukuran validitas sebanyak 20 pernyataan memiliki nilai koefisien korelasi $r_{x y}$ lebih besar dari rtabel. Dengan demikian seluruh pernyataan dinyatakan valid dan layak digunakan sebagai instrumen nontes untuk mengukur minat belajar peserta didik. 
1306 Media Komik Elektronik Terintegrasi Augmented Reality dalam Pembelajaran Sistem Peredaran Darah Manusia di Sekolah Dasar - Kartika Dwi Ningrum, Erry Utomo, Arita Marini, Bramianto Setiawan

DOI: https://doi.org/10.31004/basicedu.v6i1.2289

2. Uji Realibilitas Instrumen

Realibilitas merujuk pada pengertian bahwa sebuah instrumen memiliki tingkat kepercayaan sehingga layak digunakan sebagai alat untuk memperoleh data karena instrumen tersebut sudah baik.

Tabel 10. Hasil Uji Realibilitas Instrumen

\begin{tabular}{cccc}
\hline Variabel & Crobnbach's alpha & Taraf Signifikan & Keterangan (sig.>0,60) \\
\hline Non tes & 0,974 & 0,60 & Reliabel \\
\hline
\end{tabular}

Berdasarkan Tabel 10 diketahui bahwa reliabilitas nontes minat belajar IPA mencapai skor 0,974 lebih besar dari taraf signifikansi sebesar 0,60. Skor tersebut mengindikasikan bahwa instrumen nontes tersebut reliabel atau konsisten digunakan sebagai alat untuk mengukur minat belajar IPA peserta didik.

\section{Hasil Uji Prasyarat Analisis}

\section{Uji Normalitas}

Uji normalitas digunakan sebagai dasar untuk mengetahui apakah sample data berasal dari populasi yang berdistribusi normal atau tidak. Pengujian normalitas menggunakan uji kolmogorov smirnov dengan bantuan SPSS 25.0 for windows. Berikut ini adalah hasil analisis uji normalitas kelas eksperimen dan kelas kontrol yang disajikan dalam bentuk tabel.

Tabel 11. Hasil Uji Normalitas

\begin{tabular}{llcccccc}
\hline \multirow{2}{*}{ Kelas } & \multicolumn{2}{c}{ Kolmogorov-Smirnov } & \multicolumn{3}{c}{ Shapiro-Wilk } \\
\cline { 3 - 8 } & & Statistik & df & Sig. & Statistik & df & Sig. \\
\hline Pre-test & Eksperimen & 0,143 & 25 & 0,200 & 0,938 & 25 & 0,131 \\
\hline \multirow{2}{*}{ Post-test } & Kontrol & 0,172 & 22 & 0,091 & 0,931 & 22 & 0,131 \\
\hline & Eksperimen & 0,135 & 25 & 0,200 & 0,977 & 25 & 0,813 \\
\hline & Kontrol & 0,153 & 22 & 0,194 & 0,933 & 22 & 0,139 \\
\hline
\end{tabular}

Data dikatakam berdistribusi normal apabila memiliki nilai signiikansi $>0,05$. Dari hasil uji normalitas Kolmogorov Smirnov dan Shapiro-Wilk di atas, data dapat disimpulkan bahwa data berdistribusi normal dikarenakan tidak terdapat nilai signifikansi dari data yang $<0,05$.

\section{Uji Homogenitas}

Untuk menguji apakah dua kelompok sample dalam penelitian ini berasal dari populasi yang sama dan memiliki varian data yang homogen, maka dilakukan uji homogenitas. Uji homogenitas yang digunakan ini uji Lavene's statistic dengan bantuan SPSS 25.0 for windows. Hasil analisis uji homogenitas minat belajar IPA yang disajikan dalam tabel:

Tabel 12. Hasil Uji Homogenitas

\begin{tabular}{llcccc}
\hline & & Levene Statistic & df1 & Df2 & Sig. \\
\hline \multirow{3}{*}{ Pre-test } & Based on Mean & 0,162 & 1 & 45 & 0,689 \\
\cline { 2 - 5 } & Based on Median & 0,049 & 1 & 45 & 0,825 \\
\cline { 2 - 6 } & Based on Median and with adjusted df & 0,049 & 1 & 44,970 & 0,825 \\
\cline { 2 - 5 } & Based on trimmed mean & 0,154 & 1 & 45 & 0,696 \\
\hline \multirow{2}{*}{ Post-test } & Based on Mean & 0,004 & 1 & 45 & 0,951 \\
\cline { 2 - 6 } & Based on Median & 0,006 & 1 & 45 & 0,938 \\
\cline { 2 - 6 } & Based on Median and with adjusted df & 0,006 & 1 & 40,133 & 0,938 \\
\hline
\end{tabular}


1307 Media Komik Elektronik Terintegrasi Augmented Reality dalam Pembelajaran Sistem Peredaran Darah Manusia di Sekolah Dasar - Kartika Dwi Ningrum, Erry Utomo, Arita Marini, Bramianto Setiawan

DOI: https://doi.org/10.31004/basicedu.v6i1.2289

Based on trimmed mean

0,004

1

45

0,952

Data dikatakan homogen apabila memiliki tingkat sig $>0,05$. Untuk hasil uji homogenitas di atas menunjukkan bahwa data homogen dikarenakan tidak terdapat signifikansi yang $<0,05$. Maka uji T dilakukan dengan uji parametrik yaitu Independent Sample t-Test.

\section{Uji Beda Rata-rata}

Uji beda rata-rata ini dilakukan untuk mengetahui apakah kelas eksperimen dan kelas kontrol memiliki kemampuan awal yang sama atau berbeda. Uji beda rata-rata dalam penelitian ini menggunakan uji independent sample t-test dengan bantuan SPSS 25.0 for windows. Hasil uji beda rata-rata minat belajar IPA kedua kelas disajikan dalam tabel 13.

Tabel 13. Hasil Uji Descriptive Statistics

\begin{tabular}{lllccc}
\hline & Kelas & N & Mean & Std. Deviation & Std. Error Mean \\
\hline Pre-test & Eksperimen & 22 & 40,14 & 5,792 & 1,235 \\
\hline & Kontrol & 25 & 38,56 & 5,817 & 1,163 \\
\hline Post-test & Eksperimen & 22 & 82,28 & 7,199 & 1,535 \\
\hline & Kontrol & 25 & 66,44 & 8,016 & 1,603 \\
\hline
\end{tabular}

Berdasarkan tabel 13 diketahui jumlah responden kelas eksperimen adalah 22 siswa dan kelas kontrol 25 siswa. Perolehan nilai rata-rata minat belajar IPA awal dari masing-masing kelas sebesar 40,14 untuk kelas eksperimen dan 38,56 untuk kelas kontrol. Data deskriptive statistics menunjukkan ada perbedaan rata-rata antara kelas eksperimen dan kelas kontrol. Untuk mengetahui signifikansi data tersebut dilakukan pengujian dengan uji independent sample t-test pada tabel 14.

Tabel 14 Hasil Uji Beda Rata-rata Minat Belajar IPA

\begin{tabular}{ccccc}
\hline Kelas & $\begin{array}{c}\text { Equal Variances } \\
\text { Assumed }\end{array}$ & $\begin{array}{c}\text { Equal Variances } \\
\text { Not Assumed }\end{array}$ & $\begin{array}{c}\text { Taraf } \\
\text { Signifikansi }\end{array}$ & $\begin{array}{c}\text { Keterangan } \\
\text { (Sig }>\mathbf{0 , 0 5})\end{array}$ \\
\hline Eksperimen dan Kontrol & 0,02 & 0,02 & 0,05 & Ada perbedaan \\
\hline
\end{tabular}

Berdasarkan tabel 14 diketahui nilai equal variances assumed sebesar 0,02. Hal ini menunjukkan bahwa nilai signifikansi lebih kecil dari 0,05. Ini berarti ada perbedaan rata-rata minat belajar IPA awal antara kelas eksperimen dan kelas kontrol, sehingga kedua kelas memiliki kemampuan minat belajar IPA yang berbeda.

Peningkatan (gainscore) minat belajar IPA didapatkan dari selisih prosentase sebelum adanya perlakuan (pretest) dan setelah adanya perlakuan (postest). Untuk mengetahui keefektifan penggunaan media komik elektronik sistem peredaran darah manusia terintegrasi augmented reality pada kelas eksperimen dan kelas kontrol digunakan perhitungan Gain ternormalisasi ( $N$-Gain). Hasil perhitungan $N$ - Gain kelas eksperimen dan kelas kontrol dapat dilihat pada tabel 15.

Tabel 15. Hasil Perhitungan Uji $N$-gain Score

\begin{tabular}{ccccr}
\hline Kelas & Rata-rata pretest & Rata-rata postest & N-Gain & Kriteria \\
\hline Eksperimen & 40,14 & 82,27 & 70,1773 & Tinggi \\
\hline Kontrol & 38,56 & 66,44 & 45,0704 & Sedang \\
\hline
\end{tabular}


1308 Media Komik Elektronik Terintegrasi Augmented Reality dalam Pembelajaran Sistem Peredaran Darah Manusia di Sekolah Dasar - Kartika Dwi Ningrum, Erry Utomo, Arita Marini, Bramianto Setiawan

DOI: https://doi.org/10.31004/basicedu.v6i1.2289

Dengan rata-rata $N$-Gain Score untuk kelas kontrol sebesar 45,07 dan kelas eksperimen 70,17 maka kelompk kontrol termasuk dalam kategori kurang efektif, sedangkan kelompok eksperimen termasuk kategori efektif dikarenakan nilai mean $>70$. Untuk uji beda rata-rata $N$-Gain score juga menunjukkan terdapat perbedaan yang signifikan di antara kedua kelopok tersebut.

Selanjutnya, untuk melihat perbedaan rata-rata antara kelompok eksperimen yang menggunakan media komik elektronik sistem peredaran darah manusia terintegrasi augmented reality dan kelompok kontrol yang menggunakan bahan ajar konvensional menggunakan uji independent sample t-test. Hasil uji independent sample t- test pada kelas eksperimen dan kelas kontrol diperoleh data seperti pada tabel 16.

Tabel 16. Hasil Uji Descriptive Statistics Kelas Eksperimen dan Kelas Kontrol

\begin{tabular}{llrrrr}
\hline & \multicolumn{1}{c}{ Kelas } & N & Mean & Std. Deviation & Std. Error Mean \\
\hline \multirow{2}{*}{ post } & Kelas Eksperimen & 22 & 82,27 & 7,199 & 1,535 \\
\cline { 2 - 6 } & Kelas Kontrol & 25 & 66,44 & 8,016 & 1,603 \\
\hline
\end{tabular}

Dari tabel 16 hasil perhitungan Group Statistic, jumlah responden yang diuji berasal dua kelas yang berbeda dengan 22 responden dari kelas ekperimen dan 25 responden dari kelas kontrol. Perolehan nilai ratarata dari masing-masing kelas sebesar 82,27 untuk kelas eksperimen, sedangkan untuk kelas kontrol sebesar 66,44 . Dengan hasil tersebut dapat disimpulkan, terdapat perbedaan rata-rata hasil akhir minat belajar IPA siswa antara kelas eksperimen dan kelas kontrol. Signifikan dan tidaknya perbedaan berdasarkan hasil deskriptif dibuktikan dengan uji independent sample t-tes pada tabel 17.

Tabel 17. Hasil Uji Independent Sample T-Test

\begin{tabular}{cccc}
\hline Kelas & Sig.(2-tailed) & $\begin{array}{c}\text { Taraf } \\
\text { Signifikansi }\end{array}$ & $\begin{array}{c}\text { Keterangan } \\
(\text { Sig }<\mathbf{0 , 0 5})\end{array}$ \\
\hline Eksperimen dan Kontrol & 0,000 & 0,05 & Ada perbedaan \\
\hline
\end{tabular}

Berdasarkan tabel 17 output independent sample t-test diketahui nilai Sig. (2-tailed) sebesar 0,000< 0,05, maka sebagaimana dasar pengambilan keputusan dalam uji independent sample t-test diperoleh hasil, Ho ditolak dan Ha diterima. Artinya, ada perbedaan yang signifikan antara rata-rata minat belajar IPA siswa pada kelas yang menggunakan media komik elektronik sistem peredaran darah manusia terintegrasi augmented reality dengan kelas yang tidak menggunakan media komik elektronik sistem peredaran darah manusia terintegrasi augmented reality.

\section{KESIMPULAN}

Telah berhasil dibuat media pembelajaran komik elektronik sistem peredaran darah manusia terintegrasi augmented reality untuk meningkatkan minat belajar IPA sekolah dasar. Dari hasil validasi oleh ahli materi, ahli bahasa dan ahli media, guru kelas 5 dan uji keterbacaan oleh peserta didik menunjukkan bahwa media pembelajaran yang dikembangkan sangat layak dan dapat digunakan sebagai sumber belajar. Selain itu, Efektivitas Media komik elektronik sistem peredaran darah manusia terintegrasi augmented reality yang dikembangkan melalui uji coba lapangan menunjukkan perbedaan hasil minat belajar IPA peserta didik yang signifikan antara kelas kontrol dan kelas eksperimen. Perbedaan hasil yang signifikan antara kelas kontrol dan kelas eksperimen yang dibuktikan melalui angket menunjukkan bahwa media komik elektronik sistem peredaran darah manusia terintegrasi augmented reality sangat efektif dalam meningkatkan minat belajar IPA kelas 5 sekolah dasar. 
1309 Media Komik Elektronik Terintegrasi Augmented Reality dalam Pembelajaran Sistem Peredaran Darah Manusia di Sekolah Dasar - Kartika Dwi Ningrum, Erry Utomo, Arita Marini, Bramianto Setiawan

DOI: https://doi.org/10.31004/basicedu.v6i1.2289

\section{DAFTAR PUSTAKA}

Agatha, N. D., Prihatin, J., \& Narulita, E. (2018). Pengembangan Buku Komik Pokok Bahasan Sistem Peredaran Darah. Jurnal Bioedukatika, 5(2), 59. Https://Doi.Org/10.26555/Bioedukatika.V5i2.7200

Al-Shara, I. (2015). Learning And Teaching Between Enjoyment And Boredom As Realized By The Students : A Survey From The Educational Field. 11(19), 146-168.

Arroio, A. (2011). Comics As A Narrative In Natural Science Education. Western Anatolia Journal Of Educational Science, July 2011, 93-98.

Creswell, J. W. (2011). Controversies In Mixed Methods Research. The Sage Handbook Of Qualitative Research, 4, 269-284.

Daryanto. (2010a). Media Pembelajaran: Peranannya Sangat Penting Dalam Mencapai Tujuan Pembelajaran. Gava Media.

Daryanto. (2010b). Media Pembelajaran: Peranannya Sangat Penting Dalam Mencapai Tujuan Pembelajaran. Gava Media.

Derbel, E. (2019). Teaching Literature Through Comics: An Innovative Pedagogical Tool. International Journal Of Applied Linguistics And English Literature, 8(1), 54-61.

Dick, W., L. Carey, J., \& Carey, O. (2005). The Systematic Design Of Instruction. Logman.

Djaali. (2011). Psikologi Pendidikan. Pt Bumi Aksara.

Fakhrudin. (2019). Implementation Of Augmented Reality Technology In Natural Sciences Learning Of Elementary School To Optimize The Students Learning Result. International Journal Of Indonesian Education And Teaching (Ijiet), 3(1), 1-10.

Heru Dwi Waluyanto. (2005). Komik Sebagai Media Komunikasi Visual Pembelajaran. Nirmana.

Jampel, I. N., Artawan, G., Widiana, I. W., Parmiti, D. P., \& Hellman, J. (2018). Jurnal Pendidikan Ipa Indonesia Studying Natural Science In Elementary School Using Nos-Oriented Cooperative Learning Model With The Nht Type. 7(2), 138-146. Https://Doi.Org/10.15294/Jpii.V7i2.9863

Kalyani, D., \& Rajasekaran, K. (2018). Innovative Teaching And Learning. 3, 23-25.

Lestari, K. E., \& Yudhanegara, M. R. (2017). Penelitian Pendidikan Matematika. In Pt.Refika Aditama. Refika Aditama.

Lin, S. F., Lin, H. Shyang, Lee, L., \& Yore, L. D. (2015). Are Science Comics A Good Medium For Science Communication? The Case For Public Learning Of Nanotechnology. International Journal Of Science Education, Part B: Communication And Public Engagement, 5(3), 276-294. Https://Doi.Org/10.1080/21548455.2014.941040

Meidasari, V. E. (2016). The Using Of Digital Media To Enhance Teaching And Learning English On The Well-Being Of Indonesian Students. Journal Of English Language And Culture, 6.

Nadeak, B. (2020). The Effectiveness Of Distance Learning Using Social Media During The Pandemic Period Of Covid-19: A Case In Universitas Kristen Indonesia. International Journal Of Advanced Science And Technology, 29(7), 1764-1772.

Nicolas, Y., Kwarrie, P., \& Radion, K. (2015). Media Interaktif Pembelajaran Sistem Peredaran Darah Manusia. Infra, 3(2).

Nurharyani, D., Sardimi, \& Jumrodah. (2015). Pengaruh Media Animasi Terhadap Hasil Belajar Konsep Sistem Peredaran Darah Manusia Siswa Kelas Viii Mts Raudhatul Jannah Palangkaraya. Edusains, 3(2), 1.

Nurhasanah, Z., Widodo, A., \& Riandi, R. (2019). Augmented Reality To Facilitate Students Biology Mastering Concepts And Digital Literacy. Jpbi (Jurnal Pendidikan Biologi Indonesia), 5(3), 481-488. 
1310 Media Komik Elektronik Terintegrasi Augmented Reality dalam Pembelajaran Sistem Peredaran Darah Manusia di Sekolah Dasar - Kartika Dwi Ningrum, Erry Utomo, Arita Marini, Bramianto Setiawan

DOI: https://doi.org/10.31004/basicedu.v6i1.2289

Https://Doi.Org/10.22219/Jpbi.V5i3.9694

Panjaitan, R. G. P., \& Savitri, E. (2016). Pengembangan Media E-Comic Bilingual Sub Materi Saluran Dan Kelenjar Pencernaan. Unnes Science Education Journal, 5.

Siregar, H. F., \& Melani, M. (2019). Perancangan Aplikasi Komik Hadist Berbasis Multimedia. Jurnal Teknologi Informasi. Https://Doi.Org/10.36294/Jurti.V2i2.425

Slameto. (2010). Belajar Dan Faktor-Faktor Yang Mempengaruhi. Pt Rineka Cipta.

Talebzadeh, F., \& Samkan, M. (2011). Happiness For Our Kids In Schools : A Conceptual Model. Procedia Social And Behavioral Sciences, 29, 1462-1471. Https://Doi.Org/10.1016/J.Sbspro.2011.11.386

Wahyu, Y., Suastra, I. W., Sadia, I. W., \& Suarni, N. K. (2020). The Effectiveness Of Mobile Augmented Reality Assisted Stem Based Learning On Scientific Literacy And Students Achievement. International Journal Of Instruction, 13(3), 343-356. Https://Doi.Org/10.29333/Iji.2020.13324a 